\title{
Saber médico e ciências sociais no Brasil
}

\author{
Medical knowledge and social \\ science in Brazil
}

\author{
Anny Jackeline Torres Silveira \\ Professora do Colégio Técnico da Universidade Federal de Minas Gerais (Coltec/UFMG) \\ Rua Maracanã, 57/25, Santa Efigênia \\ 30260-180 Belo Horizonte - MG Brasil \\ anejack@gold.com.br
}

\footnotetext{
Q
} ual papel pode ser atribuído ao saber médico na elaboração e construção do pensamento social no Brasil e qual a dimensão e a capacidade de intervenção que este saber alcançou no exercício de qualificar e de propor resoluções aos problemas sociais? Estas são questões que nos levanta o trabalho de Ferreira Antunes. Pensar sobre o sentido e o modo como a medicina se dirigiu, problematizou e interveio nestas questões sociais abre a possibilidade para se discutir também a aplicação e a validade de um conceito bastante generalizado nos últimos tempos: o da medicalização. A partir dos problemas, dos exemplos e da análise estabelecidos pelo autor, buscaremos apontar os caminhos que ele nos sugere para esclarecer estas perguntas.

Conforme Antunes, o pensamento médico pode ser tomado como uma matriz interpretativa da reflexão sobre as questões sociais no Brasil. Durante o final do século XIX e o início do século XX os médicos participaram de forma ativa na elaboração de reflexões a respeito de questões relativas ao convívio social, em especial, aquelas que envolviam os fatos morais. No entanto, este papel não é freqüentemente reconhecido (assim como a reflexão produzida), nem pelos cientistas sociais nem pelos médicos, em particular os especialistas em medicina legal. Esta omissão pode ser entendida a partir da demarcação das especificidades próprias a cada disciplina e a atividade profissional.

É possível identificar, tanto entre os cientistas sociais como entre os médicos legistas, uma perspectiva de viés corporativista no reconhecimento das origens de suas áreas de saber. $O$ que define a inclusão ou pertencimento nestas áreas muitas vezes é definido por uma visão que busca reconhecer no passado elementos característicos destes saberes no presente: conceitos, métodos, princípios doutrinários, temáticas, entre outros. Segundo o autor, isto acabou levando a uma interpretação negativa, à medida que se "procurou entender as formações pretéritas por meio de características ausentes, ... e que desvalorizava o passado como falta, como privação" (p. 20). Nesta passagem o autor refere-se especificamente à medicina legal, mas parece ser possível ampliar esta perspectiva também para as ciências sociais.

No âmbito das ciências sociais, os profissionais que se dedicam a resgatar o seu passado têm, comumente, restringido a reflexão a respeito dos temas sociais ao "campo institucional sob seu domínio" (p. 24), instituído a partir de 1930 com a criação dos primeiros cursos superiores dedicados às ciências 
sociais. O reconhecimento destas reflexões dependia do fato de estarem informadas pelas especulações teóricas e os procedimentos metodológicos próprios da disciplina, de se abrigarem sob as instituições representativas da área e de serem reconhecidas e/ou sancionadas pelos colegas de profissão. A produção intelectual sobre os temas sociais do período anterior é tomada como "fase pioneira" ou classificada como pré-científica, em que predominariam obras de cunho antes histórico e literário do que sociológico. Esta forma de abordar o passado acaba por omitir o papel que a medicina, em especial a medicina legal, representou na construção de uma reflexão a respeito dos temas relativos à vida social no Brasil.

A desqualificação ou negação da importância desta produção sobre as questões sociais como parte integrante do seu campo de reflexão é observada também entre os próprios médicos legistas. Sua história tem sido recuperada através da produção dos seus autores mais destacados ou de uma tríplice perspectiva: o ensino da disciplina, sua inserção na legislação e a atuação dos institutos periciais. O modelo da medicina experimental e o peso e predomínio que o conteúdo técnico alcançaram neste campo de conhecimento também influem na escolha do passado a ser recuperado: aquele que esteja "convenientemente enquadrado" no perfil da medicina legal que se institui a partir destas bases. Assim, grande parte do pensamento produzido no período destacado pelo livro será tratado pelos profissionais da área como não técnico, pouco científico, portanto, indigno de ser tomado sob esta rubrica.

Para fugir a estas armadilhas, o autor propõe uma abordagem "funcionalista" - "de forma exterior, sem preestabelecer conceitos que restrinjam a sua visualização, sem os condicionamentos que firmam a identidade da disciplina para os seus profissionais" (p. 23), sem se deixar guiar pela imagem que estas profissões criam sobre si mesmas ou pelo ciclo evolutivo que estabelecem para sua especialidade. Em vez de privilegiar exclusivamente as instituições, os grandes nomes, os métodos e doutrinas, ele se volta para os temas, os assuntos que foram objeto de reflexão e de intervenção dos profissionais da área médica. Se esta estratégia permite revelar uma nova perspectiva da história da medicina legal e da reflexão social no Brasil, a interseção entre estes campos de saber permite também que se coloque em questão o conceito de medicalização.

A noção da medicalização, como significando a capacidade do saber médico de se apropriar de problemas cotidianos revestindo-os de um significado e explicações oriundos da própria disciplina - isto é, enquadrando-os como questões a serem refletidas e resolvidas por este saber - pode ser problematizada a partir de pontos diversos. Uma delas pela imprecisão conceitual que o autor identifica no termo, uma vez que este não pressupõe uma caracterização do fenômeno assim nomeado. Por exemplo, a expressão "medicalização do crime" não significa que este fato (crime) tenha se transformado ou adquirido um sentido médico. O termo medicalização normalmente se refere mais ao pensamento médico sobre determinados temas, um tipo de enfoque, "uma arquitetura de idéias" que aos objetos ou assuntos por ele nomeados, ou aos quais este pensamento se aplica.

Trabalhando as questões médico-legais selecionadas e os temas relativos ao crime, ao sexo e à morte, o autor revela como as reflexões e as prescrições 
sobre eles produzidas pelo saber médico seguiram trilhas tortuosas e muitas vezes a partir de posições opostas, evidenciando conflitos nas suas percepções e propostas. O insucesso dos médicos na imposição das suas prescrições sobre as questões morais da sociedade inviabiliza a crença de que a ação médica neste campo "tivesse se orientado por um padrão racional uniforme. Que houvesse existido um conjunto de preceitos e diretrizes comportamentais logicamente articulado, algo que com propriedade se pudesse nomear 'racionalidade médica"' (p. 273).

Não há alteração na dimensão moral dos fatos sociais assim nomeados, nem a medicina alcança uma capacidade tão ampla de intervenção na realidade como sugerida pelo termo. Para o autor, a expressão medicalização se preservaria por um sentido: "para designar um processo historicamente datado de modificação da própria medicina, uma reorientação de seus objetos e métodos, um deslocamento de seu foco preferencial de observação e análise: das doenças de nossa constituição biológica para os males de nossa conformação moral” (p. 274). Em vista disso, mais adequado que recorrer à expressão medicalização da sociedade, seria referir-se a uma "socialização da medicina", evidenciando o fato de que, se mudanças há, elas se inscrevem no pensamento e na atividade médicos, submetidos às demandas sociais. Indo mais longe, o autor propõe ainda outro termo para nomear tal processo: o de "humanização da medicina", "para sublinhar sua conversão aos temas e aos procedimentos das ciências humanas" (p. 275).

De tal forma, é possível então estabelecer um papel ativo ao saber médico no exame e na proposição de resoluções dos problemas sociais, em especial os de caráter moral, experimentados pela sociedade brasileira de fins do século XIX e início do século XX. Isto significa afirmar a condição deste saber como uma matriz interpretativa importante no desenvolvimento do pensamento social brasileiro. Este papel ativo, porém, não deve ser avaliado como uma apropriação ou enquadramento dos fatos sociais pelo saber médico, mas uma interação deste saber nos fenômenos sociais - chegando ao outro extremo, Antunes afirma que "a sociedade modela a medicina e não vice-versa" (p. 275). Fica, porém, evidenciado o caráter controverso da noção de medicalização, apresentando mais um caminho possível para a discussão sobre sua generalização e a validade de sua aplicação.

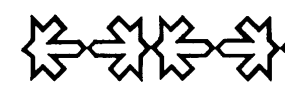

